\title{
PENERAPAN MODEL PEMBELAJARAN KOOPERATIF PADA MATA PELAJARAN MATEMATIKA BERDASARKAN KURIKULUM 2013 DI KELAS VII SMPN 13 BANJARMASIN
}

\author{
Fatmawati \& Sessi Rewetty Rivilla
}

\begin{abstract}
Abstrak
Kurikulum 2013 menekankan kepada pembelajaran dengan menggunakan pendekatan scientific dan penilaian autentik guna mewujudkan generasi yang siap menghadapi masa depan. Model pembelajaran kooperatif merupakan model pembelajaran yang menggunakan kerjasama tim. Dimana model ini mampu membantu peserta didik, memahami konsep yang sulit, menumbuhkan kemampuan berpikir kritis, dan kerjasama. Penelitian ini bertujuan untuk mengetahui penerapan model pembelajaran kooperatif pada mata pelajaran matematika berdasarkan Kurikulum 2013 di kelas VII SMPN 13 Banjarmasin.

Jenis penelitian ini adalah penelitian lapangan dengan pendekatan kualitatif. Metode yang digunakan adalah metode deskriptif. Subjek dalam penelitian ini adalah satu orang guru yang mengajar matematika di kelas VII SMPN 13 Banjarmasin. Dan objek penelitiannya adalah penerapan model pembelajaran kooperatif pada mata pelajaran matematika berdasarkan Kurikulum 2013.

Berdasarkan hasil penelitian dapat disimpulkan bahwa dalam perencanaan guru mencantumkan langkah-langkah pendekatan scientific yang mengandung komponen mengamati, menanya, mencoba, menalar, dan mengkomunikasikan, dan juga menggunakan penilaian autentik. Namun pada RPP yang dibuat guru, guru belum mencantumkan langkah-langkah model pembelajaran kooperatif. Sedangkan dalam pelaksanaannya, pembelajaran menggunakan pendekatan scientific dan model pembelajaran kooperatif terlaksana dengan baik. Penilaian autentik yang digunakan guru mencakup aspek pengetahuan, sikap, dan keterampilan.
\end{abstract}

Kata Kunci: Model Pembelajaran Kooperatif, Kurikulum 2013 


\section{Pendahuluan}

Salah satu masalah besar dalam bidang pendidikan di Indonesia yang banyak diperbincangkan adalah rendahnya mutu pendidikan yang tercermin dari rendahnya rata-rata prestasi belajar. Direktorat Pembinaan Sekolah Menengah Atas, Direktorat Manajemen Pendidikan Dasar dan Menengah, Depdiknas (2008) menjelaskan bahwa proses pendidikan dalam sistem persekolahan di Indonesia, umumnya belum menerapkan pembelajaran sampai peserta didik menguasai materi pembelajaran secara tuntas. Akibatnya, banyak peserta didik yang tidak menguasai materi pembelajaran meskipun sudah dinyatakan tamat dari sekolah. Hal ini salah satu penyebab mutu pendidikan secara nasional masih rendah.

Masalah lain dalam dunia pendidikan adalah bahwa pendekatan dalam pembelajaran masih terlalu didominasi oleh peran guru (teacher centered). Guru lebih banyak menempatkan peserta didik sebagai objek dan bukan sebagai subjek didik. Pendidikan di Indonesia kurang memberikan kesempatan kepada peserta didik dalam berbagai mata pelajaran, untuk mengembangkan kemampuan berpikir holistic (menyeluruh), kreatif, objektif, dan logis, serta kurang memperhatikan ketuntasan belajar secara individual.

Menurut Mulyono (2011 : 3) dalam bukunya“Strategi Pembelajaran" mengatakan bahwa dalam berbicara tentang rendahnya daya serap atau prestasi belajar, atau belum terwujudnya keterampilan proses dan pembelajaran yang menekankan pada peran aktif peserta didik, maka hal yang menjadi persoalan adalah pada masalah ketuntasan belajar peserta didik, yakni berupa pencapaian taraf penguasaan minimal yang ditetapkan bagi setiap kompetensi secara perorangan. Dan masalah ketuntasan belajar peserta didik ini merupakan masalah yang penting sebab menyangkut masa depan peserta didik, terutama bagi mereka yang mengalami kesulitan belajar.

Untuk memperbaiki kualitas pendidikan yang rendah, maka secara bertahap terjadi pembaharuan demi meningkatkan mutu pendidikan di 
Penerapan Model Pembelajaran Kooperatif Pada Mata Pelajaran Matematika Berdasarkan Kurikulum 2013 Di Kelas VII SMPN 13 Banjarmasin

Indonesia. Mulai dari perbaikan bangunan dan fasilitas sekolah, pembaharuan strategi sampai metode mengajar, bahkan dewasa ini kurikulum pendidikan pun mulai dilakukan pembaharuan agar bisa mencapai tujuan pendidikan yang diharapkan.

Perubahan dalam dunia pendidikan juga terjadi dalam pembaharuan kurikulumnya, dimana Kurikulum Tingkat Satuan Pendidikan (KTSP) direvisi menjadi Kurikulum 2013. Berkaitan dengan perubahan kurikulum, berbagai pihak menganalisis dan melihat perlunya diterapkan kurikulum berbasis kompetensi sekaligus berkarakter, yang dapat membekali peserta didik dengan berbagai sikap dan kemampuan sesuai dengan tuntutan perkembangan zaman dan teknologi. Kurikulum berbasis karakter dan kompetensi diharapkan mampu memecahkan berbagai persoalan bangsa, khususnya dalam bidang pendidikan, dengan cara mempersiapkan peserta didik melalui perencanaan, pelaksanaan, dan evaluasi terhadap sistem pendidikan secara efektif, efisien, dan berhasil guna. Oleh karena itu pemerintah menjadikan pengembangan pendidikan berkarakter dalam seluruh jenis dan jenjang pendidikan termasuk dalam pengembangan Kurikulum 2013.

Upaya pengembangan kurikulum ini bertujuan untuk mewujudkan sistem pendidikan nasional yang kompetitif dan selalu relevan dengan perkembangan zaman yang senantiasa menjadi tuntutan. Hal ini sejalan dengan Undang-Undang RI Nomor 20 Tahun 2003 tentang Sisdiknas pasal 35 dan 36 yang menekankan perlunya peningkatan standar nasional pendidikan sebagai acuan kurikulum secara berencana dan berkala dalam rangka mewujudkan tujuan pendidikan nasional, serta sejalan dengan Peraturan Pemerintah Nomor 32 Tahun 2013 yang merupakan revisi dari Peraturan Pemerintah Nomor 19 Tentang Standar Pendidikan Nasional.

Menurut Aqib (2011 : 3) Pendidikan karakter merupakan segala upaya yang dilakukan guru untuk mempengaruhi karakter peserta didik sehingga akan membantu membentuk watak peserta didik, melalui penanaman nilai-nilai karakter yang meliputi komponen pengetahuan, 
kesadaran atau kemauan, dan tindakan untuk melaksanakan nilai-nilai tersebut. Menurut Mulyasa (2013 : 7) pendidikan karakter dalam Kurikulum 2013 bertujuan untuk meningkatkan mutu proses dan hasil pendidikan, yang mengarah pada pembentukan budi pekerti dan akhlak mulia peserta didik secara utuh, terpadu, dan seimbang, sesuai dengan Standar Kompetensi Lulusan pada setiap satuan pendidikan.

Implementasi Kurikulum 2013 mengharapkan agar pembelajaran berpusat pada peserta didik (student centered) dimana proses pembelajaran yang dikehendaki adalah pembelajaran yang mengedepankan pengalaman personal melalui observasi, asosiasi, bertanya, menyimpulkan, dan mengkomunikasikan. Seiring dengan tanggung jawab profesional pengajar dalam proses pembelajaran, maka dalam melaksanakan kegiatan pembelajaran setiap guru dituntut untuk selalu mempersiapkan segala sesuatu yang berhubungan dengan program pembelajaran yang akan berlangsung. Tujuannya adalah agar kegiatan pembelajaran dapat berjalan secara efektif dan efisien, yaitu tujuan akhir yang diharapkan dapat dikuasai oleh semua peserta didik. Dalam rangka pencapaian tujuan pembelajaran ini, setiap guru dituntut untuk benar-benar memahami pendekatan yang diterapkannya. Pemilihan pendekatan pembelajaran dikatakan tepat, yaitu apabila dengan situasi dan kondisi yang dihadapi akan berdampak pada tingkat penguasaan atau prestasi belajar peserta didik yang dihadapi. Dan beragam pendekatan pembelajaran yang diterapkan dalam proses belajar mengajar ini merupakan salah satu upaya untuk mencapai ketuntasan belajar peserta didik, sehingga pembelajaran di kelas tidak monoton dan pembelajaran tidak hanya berpusat pada guru tetapi melibatkan partisipasi peserta didik sehingga peserta didik tidak hanya berperan sebagai pendengar, namun juga aktif berpartisipasi dalam pembelajaran.

Proses pembelajaran pada Kurikulum 2013 untuk jenjang SMP dan SMA atau yang sederajat dilaksanakan menggunakan pendekatan scientific (pendekatan berbasis sains). Menurut Mida (2013 : 116) pendekatan scientific adalah pendekatan yang dalam pembelajarannya mendorong 
Penerapan Model Pembelajaran Kooperatif Pada Mata Pelajaran Matematika Berdasarkan Kurikulum 2013 Di Kelas VII SMPN 13 Banjarmasin

peserta didik untuk berpikir lebih baik dalam melakukan observasi, bertanya, bernalar, dan mengakomodasikan dengan objek pembelajaran secara langsung yakni fenomena alam, sosial, seni, dan budaya. Dalam pendekatan ini juga menuntut adanya perubahan setting dan bentuk pembelajaran tersendiri yang berbeda dengan pembelajaran konvensional dan mencakup komponen: mengamati, menanya, mencoba, mengolah, menyajikan, menyimpulkan, dan mencipta. Pendekatan ini dimaksudkan untuk memberikan pemahaman kepada peserta didik dalam mengenal, memahami berbagai materi menggunakan pendekatan ilmiah, sehingga informasi tidak hanya berasal dari guru, tetapi juga berasal dari mana saja dan kapan saja. Sedangkan untuk mengetahui hasil yang diperoleh dalam pembelajaran digunakan penilaian yang autentik. Penilaian autentik adalah penilaian yang melibatkan peserta didik di dalam tugas-tugas autentik yang bermanfaat, penting, dan bermakna. Penilaian autentik (authentic assessment) adalah pengukuran yang bermakna secara signifikan atas hasil belajar peserta didik untuk ranah sikap, keterampilan, dan pengetahuan. Penilaian tersebut mampu menggambarkan peningkatan hasil belajar peserta didik, baik dalam rangka mengobservasi, menalar, mencoba, membangun jejaring, dan lain-lain. Penilaian autentik bertujuan untuk mengukur, memonitor, dan menilai semua aspek hasil belajar yang mencakup afektif, psikomotorik, dan kognitif, baik yang tampak sebagai proses hasil pembelajaran maupun berupa perubahan dan perkembangan aktivitas serta perolehan belajar selama proses pembelajaran. Jadi, dalam implementasi Kurikulum 2013 digunakan pembelajaran dengan pendekatan scientific dan penilaian autentik.

Begitu pentingnya pendekatan scientific dalam pembelajaran, maka tentu matematika juga menjadi salah satu mata pelajaran yang harus diajarkan dengan pendekatan scientific. Pendekatan scientific yang mengedepankan pengalaman personal serta memutuhkan proses pemikiran dan penalaran sangat relevan jika diterapkan dalam pembelajaran matematika, karena dalam proses pembelajaran matematika dibutuhkan 
kemampuan yang cermat, teliti, dan tepat dalam menganalisis masalah sehingga ditemukan penyelesaian yang tepat. Matematika merupakan salah satu mata pelajaran yang ada di dalam dunia pendidikan, baik pada jenjang Sekolah Dasar, Sekolah Menengah Pertama, Sekolah Menengah Atas, Perguruan tinggi, bahkan sekarang anak-anak yang masih berada di sekolah Taman Kanak-Kanak pun mulai dikenalkan dengan matematika. Menurut Bakhtiar (2004 : 188) matematika adalah bahasa yang melambangkan serangkaian makna dari pernyataan yang ingin kita sampaikan, lambanglambang matematika bersifat artifisial yang baru mempunyai arti setelah sebuah makna diberikan padanya, tanpa itu maka matematika hanya merupakan kumpulan rumus-rumus yang mati. Pentingnya matematika tidak lepas dari perannya dalam segala jenis dimensi kehidupan. Misalnya banyak persoalan kehidupan yang memerlukan kemampuan menghitung dan mengukur.

Dalam proses pembelajaran tidak semua dapat diserap peserta didik dengan maksimal, terutama pada pelajaran matematika yang lebih banyak menguras tenaga dan pemikiran dalam menyelesaikan permasalahannya. Sebelum peserta didik mampu menyelesaikan permasalahan, peserta didik tersebut harus cakap dalam memahami model permasalahan tersebut, sehingga mampu menerapkan konsep yang sesuai dengan permasalahan tersebut. Namun ada kalanya peserta didik itu kesulitan dalam memahami konsep pada pelajaran matematika sehingga akan berpengaruh pada kegiatan selanjutnya. Ditambah lagi pembelajarannya yang masih bersifat konvensional dimana guru yang lebih berperan aktif dan peserta didik hanya sebagai pendengar yang baik. Hal ini, bisa menyebabkan kurangnya konsentrasi peserta didik dalam belajar, dimana harus diakui bahwa kegiatan belajar peserta didik menguras energi peserta didik dari pagi hingga siang, bahkan kadang sore. Kalau proses pembelajaran tidak dilakukan dengan variasi maka peserta didik akan merasa bosan dan akhirnya cenderung mengalihkan perhatian pada hal lain yang lebih menarik perhatiannya. Oleh karena itu, proses pembelajaran harus 
Penerapan Model Pembelajaran Kooperatif Pada Mata Pelajaran Matematika Berdasarkan Kurikulum 2013 Di Kelas VII SMPN 13 Banjarmasin

dirancang menyenangkan bagi para peserta didik, dimana dibutuhkan kreativitas guru dalam mengembangkan pembelajaran baik dari segi pendekatan, strategi, maupun model pembelajaran yang digunakan secara beragam.

Model pembelajaran merupakan suatu rencana yang digunakan sebagai pedoman dalam merencanakan pembelajaran sehingga dapat membantu peserta didik agar tujuan pembelajaran tercapai. Salah satu model pembelajaran yang kini banyak mendapat respon adalah model pembelajaran kooperatif (cooperative learning). Model pembelajaran kooperatif (cooperative learning) merupakan model pembelajaran yang menggunakan kerjasama tim atau pembelajaran yang dilakukan secara berkelompok. Model pembelajaran kooperatif (cooperative learning) ini juga merupakan model pembelajaran yang mengutamakan kerjasama diantara peserta didik untuk mencapai tujuan pembelajaran. Model pembelajaran kooperatif (cooperative learning) ini bertujuan agar peserta didik dapat belajar secara berkelompok bersama teman-temannya dengan cara saling menghargai pendapat dan memberikan kesempatan kepada orang lain untuk mengemukakan pendapat.

Beberapa ahli menyatakan bahwa model pembelajaran kooperatif (cooperative learning) ini mampu membantu peserta didik memahami konsep yang sulit, mampu menumbuhkan kemampuan berpikir kritis, bekerjasama, dan saling membantu teman belajar. Hal ini menyebabkan peserta didik terlibat aktif dalam pembelajaran sehingga mampu meningkatkan prestasi peserta didik dan menimbulkan dampak yang positif bagi peserta didik.

Berdasarkan yang disebutkan di atas, maka model pembelajaran kooperatif (cooperative learning) ini sangat relevan untuk digunakan dalam proses pembelajaran pada era Kurikulum 2013, dimana melalui pendekatan scientific dan model pembelajaran kooperatif (cooperative learning) akan mampu mewujudkan dan mencapai tujuan pendidikan nasional yang diharapkan. 
Pembelajaran matematika yang menggunakan pendekatan scientific juga akan sangat relevan jika menggunakan model pembelajaran yang juga mengasah daya pikir dan analisis seperti model pembelajaran kooperatif (cooperative learning). Karena melalui model pembelajaran kooperatif (cooperative learning) ini dalam pembelajaran matematika akan mampu membantu peserta didik meningkatkan sifat positif dalam berpikir dan membantu membangun kepercayaan diri dalam menyelesaikan permasalahan matematika.

Salah satu sekolah yang sudah menerapkan Kurikulum 2013 adalah SMPN 13 Banjarmasin, dimana pada saat observasi awal peneliti menemukan bahwa sekolah ini biasa menerapkan model pembelajaran kooperatif (cooperative learning) guna menyesuaikan dengan kurikulum 2013 ini. Adapun model pembelajaran kooperatif (cooperative learning) tersebut telah diterapkan dalam proses belajar mengajar di sekolah SMPN 13 ini, terutama pada mata pelajaran matematika. Bertitik tolak dari hal tersebut, maka peneliti tertarik untuk meneliti bagaimana proses penerapan model pembelajaran kooperatif (cooperative learning) ini pada pembelajaran matematika berdasarkan Kurikulum 2013. Oleh karena itu, peneliti menuangkan penelitian tersebut dalam sebuah judul "Penerapan Model Pembelajaran Kooperatif pada Mata Pelajaran Matematika Berdasarkan Kurikulum 2013 di Kelas VII SMPN 13 Banjarmasin.”

\section{Metode Penelitian}

Dalam penelitian ini penulis menggunakan jenis penelitian lapangan (field research), yakni penelitian yang dilakukan dengan terjun langsung kelapangan untuk mengetahui penerapan model pembelajaran kooperatif (cooperative learning) pada pembelajaran matematika berdasarkan Kurikulum 2013 di kelas VII SMPN 13 Banjarmasin.

Pendekatan yang digunakan dalam penelitian ini adalah pendekatan kualitatif, yakni prosedur penelitian yang menghasilkan data deskriptif berupa kata-kata tertulis/lisan dari orang-orang dan perilaku yang dapat 
Penerapan Model Pembelajaran Kooperatif Pada Mata Pelajaran Matematika Berdasarkan Kurikulum 2013 Di Kelas VII SMPN 13 Banjarmasin

diamati (Basrowi, 2008 : 21). Desain yang digunakan dalam penelitian ini adalah metode deskriptif, yaitu data yang dikumpulkan berupa kata-kata, gambaran dan bukan angka-angka. Metode penelitian deskriptif bertujuan untuk membuat penggambaran tentang suatu keadaan secara objektif, dan metode ini digunakan untuk berupaya memecahkan atau menjawab permasalahan yang sedang dihadapai pada situasi sekarang.

Peneliti menggunakan pendekatan kualitatif deskriptif ini dengan tujuan untuk mendeskripsikan tentang pelaksanaan pembelajaran matematika dengan menggunakan model pembelajaran kooperatif yang disesuaikan dengan pendekatan scientific pada pembelajaran dalam Kurikulum 2013. Sehingga akan diketahui bagaimana penerapan model pembelajaran kooperatif pada pembelajaran matematika berdasarkan Kurikulum 2013 di kelas VII SMPN 13 Banjarmasin.

Subjek penelitian ini adalah satu orang guru matematika kelas VII di SMPN 13 Banjarmasin yang mengajar di kelas VII A, VII B, VII C, VII D, dan VII E. Objek dalam penelitian ini adalah penerapan model pembelajaran kooperatif pada pembelajaran matematika berdasarkan Kurikulum 2013 di kelas VII SMPN 13 Banjarmasin.

Teknik Pengumpulan data dalam penelitian ini adalah observasi, wawancara, dan dokumentasi. Observasi dilakukan untuk mendapatkan informasi tentang peristiwa, aktivitas, perilaku, dan benda yang berkaitan dengan kegiatan pembelajaran matematika menggunakan model pembelajaran kooperatif yang disesuaikan dengan pendekatan scientific pada saat pembelajaran berlangsung. Observasi ini juga digunakan untuk memperoleh data penunjang tentang deskripsi lokasi penelitian, keadaan tenaga pendidik dan kependidikan, keadaan peserta didik, serta keadaan sarana dan prasarana di SMPN 13 Banjarmasin. Wawancara ini digunakan untuk melengkapi dan memperkuat data yang diperoleh peneliti dari teknik observasi. Teknik ini digunakan untuk memperoleh dan memperkuat data tentang deskripsi lokasi penelitian, keadaan tenaga pendidik dan kependidikan, keadaan peserta didik, serta keadaan sarana dan prasarana di 
SMPN 13 Banjarmasin. Teknik ini juga digunakan untuk memperkuat data mengenai penerapan model pembelajaran kooperatif (cooperative learning) pada saat pembelajaran matematika dan untuk mengetahui tanggapan personal sekolah terhadap Kurikulum 2013.

Data yang telah diperoleh dan diolah selanjutnya dianalisis dengan analisis yang menghubungkan teori-teori yang ada dan kesimpulannya ditarik secara induktif. Setelah data yang diperoleh diolah, selanjutnya disajikan secara deskriptif berupa uraian-uraian yang dapat memberikan gambaran tentang permasalahan yang diteliti berdasarkan fakta-fakta di lapangan, kemudian dari data deskriptif tersebut ditarik kesimpulan yang bersifat umum.

\section{Hasil Penelitian dan Pembahasan}

\section{Tahan Perencanaan}

Berdasarkan observasi dan wawancara yang dilakukan peneliti, pembuatan RPP yang dilakukan guru berpedoman dengan penyusunan RPP pada Kurikulum 2013 yang mencakup identitas sekolah, identitas mata pelajaran, kelas, alokasi waktu, tujuan pembelajaran, Kompetensi Dasar beserta indikator, materi, metode, media, sumber belajar, langkah-langkah pembelajaran, dan penilaian pembelajaran. Dalam RPP ini guru juga mencantumkan ke empat Kompetensi Inti yang menjadi pedoman dalam pembuatan RPP agar pembelajaran terlaksana dengan baik sesuai yang diharapkan dalam Kurikulum 2013. Kesesuaian perencanaan yang dibuat guru dengan tuntutan Kurikulum 2013 sudah dapat dikatakan telah sesuai.

RPP yang dibuat oleh guru tidak mencantumkan langkah-langkah model pembelajaran kooperatif secara khusus karena lebih menekankan pada komponen pendekatan scientific yang digunakan dalam proses pembelajaran seperti mengamati, menanya, mencoba, menalar, dan mengkomunikasikan, dimana semua komponen pendekatanscientific tersebut dilaksanakan dalam pembelajaran menggunakan model 
Penerapan Model Pembelajaran Kooperatif Pada Mata Pelajaran Matematika Berdasarkan Kurikulum 2013 Di Kelas VII SMPN 13 Banjarmasin

pembelajaran kooperatif. Model pembelajaran kooperatif tersebut meliputi penyampaian tujuan pembelajaran, penyajian informasi, pengorganisasian peserta didik ke dalam kelompok-kelompok kecil, membimbing kinerja kelompok, memberikan penilaian/evaluasi, dan pemberian penghargaan.

Langkah-langkah model pembelajaran kooperatif ini tidak tercantum dalam perencanaan yang dibuat guru, namun dalam proses pelaksanaan pembelajaran, langkah-langkah model pembelajaran kooperatif ini terlaksana dengan baik. Sehingga menurut peneliti, untuk perencanaan yang dibuat guru dengan menerapkan model pembelajaran kooperatif berdasarkan Kurikulum 2013 dapat dikatakan bahwa perencanaan pembelajaran ini belum dilakukan secara maksimal.

Dalam RPP yang dibuat guru ini, guru juga mencantumkan beberapa karakter yang ingin ditanamkan kepada peserta didik selama proses pembelajaran berlangsung. RPP yang dibuat guru juga mencantumkan teknik-teknik penilaian yang akan digunakan diantaranya untuk penilaian sikap spiritual guru melakukan penilaian dengan teknik penilaian diri, artinya setiap peserta didik memperoleh kesempatan untuk memberikan penilaian terhadap diri mereka sendiri yang berkaitan dengan indikator penilaian spiritual yang telah dibuat oleh guru. Untuk penilaian sikap sosial guru melakukan penilaian dengan teknik penilaian antar teman, artinya peserta didik memberikan penilaian kepada temannya sesuai indikator penilaian yang telah disiapkan oleh guru.

Selanjutnya untuk mengetahui kedalaman pengetahuan peserta didik, guru memberikan tes atau latihan soal, sedangkan untuk penilaian keterampilan, guru memberikan penilaian langsung yakni melalui pengamatan sesuai indikator yang disiapkan guru.

Secara umum, berdasarkan semua observasi yang dilakukan peneliti, guru telah membuat perencanaan terlebih dahulu, meskipun dalam pelaksanaannya ada yang tidak sesuai dengan RPP, namun hal 
tersebut tidak mengubah tujuan pembelajaran yang diharapkan artinya pembelajaran tetap berlangsung dengan baik. Oleh karena itu, dapat peneliti katakan bahwa perencanaan pembelajaran yang dilakukan oleh guru secara keseluruhan belum maksimal.

\section{Tahap Pelaksanaan}

Berdasarkan observasi yang dilakukan peneliti, guru telah melaksanakan proses pembelajaran dengan berpedoman pada RPP yang dibuat guru. Dalam pelaksanaannya, guru memadukan komponenkomponen pendekatan scientific dengan pembelajaran kooperatif, dimana komponen mengamati, menanya, mencoba, menalar, dan mengkomunikasikan dilakukan dalam pembelajaran menggunakan model pembelajaran kooperatif.

Menurut hasil wawancara dengan guru matematika, bahwa model pembelajaran kooperatif ini mampu memenuhi tuntutan Kurikulum 2013, karena komponen-komponen pendekatan scientific dapat dilakukan meskipun dalam pembelajaran kelompok, dan sejauh ini hasilnya jika sudah mencapai $85 \%$ maka dapat dikatakan tuntas dengan KKM 75. Untuk mengetahui bagaimana penerapan model pembelajaran kooperatif pada pembelajaran matematika berdasarkan Kurikulum 2013 di SMPN 13 Banjarmasin, maka dapat dilihat pada keterlaksanaan indikator-indikator model pembelajaran kooperatif berikut:

a. Menyampaikan tujuan dan mempersiapkan peserta didik

Berdasarkan hasil pengamatan peneliti, pada setiap kali observasi yang peneliti lakukan, guru telah melaksanakan tahap pertama dalam model pembelajaran kooperatif, yakni penyampaian tujuan dan mempersiapkan peserta didik. Hal ini terlihat dalam penyajian data dimana guru selalu memulai pembelajaran dengan menanyakan kabar dan mengabsen peserta didik. Guru juga selalu memberikan motivasi agar peserta didik selalu semangat dalam belajar. Hal ini menunjukkan bahwa guru telah memastikan kesiapan 
Penerapan Model Pembelajaran Kooperatif Pada Mata Pelajaran Matematika Berdasarkan Kurikulum 2013 Di Kelas VII SMPN 13 Banjarmasin

peserta didik baik dari fisik maupun psikis. Guru juga menanamkan sifat untuk selalu berdo'a dan bersyukur sebagai wujud taat manusia kepada Allah swt.

Guru senantiasa menyampaikan tujuan pembelajaran agar peserta didik mengetahui apa yang akan mereka pelajari. Akan tetapi pada observasi yang kedua, guru terlupa menyebutkan tujuan pembelajarannya padahal dalam perencanaan penyampaian tujuan pembelajaran tercantum dengan jelas. Meskipun demikian secara keseluruhan tahap pertama dalam model pembelajaran kooperatif ini telah terlaksana dengan baik.

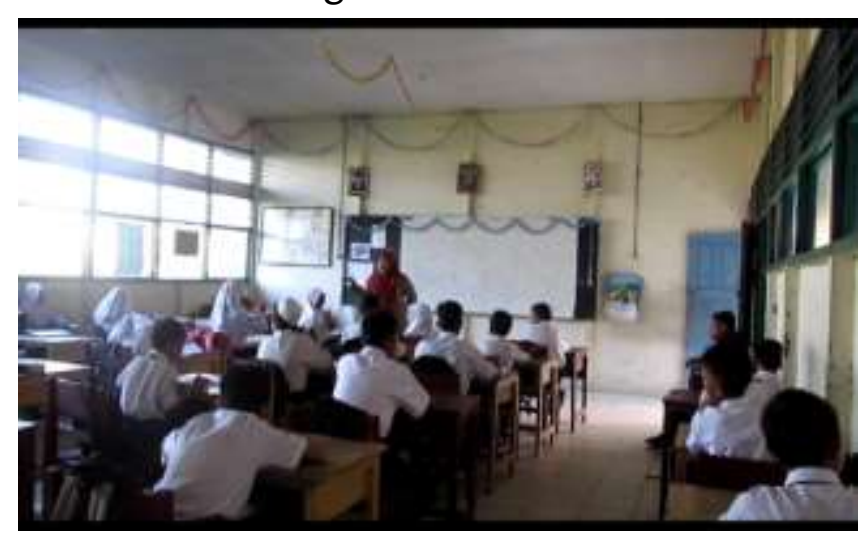

Gambar 1. Guru Menyampaikan Tujuan Pembelajaran

b. Menyajikan informasi ke peserta didik

Berdasarkan hasil observasi, guru telah melaksanakan tahap kedua dari model pembelajaran kooperatif ini. Dimana guru selalu menyajikan informasi kepada peserta didik sebelum melaksanakan kegiatan pembelajaran berupa penjelasan-penjelasan singkat mengenai pokok-pokok materi maupun langkah-langkah kegiatan pembelajaran yang akan dilakukan. Oleh karena itu, tahap kedua dalam model pembelajaran kooperatif telah terlaksana dengan baik. 


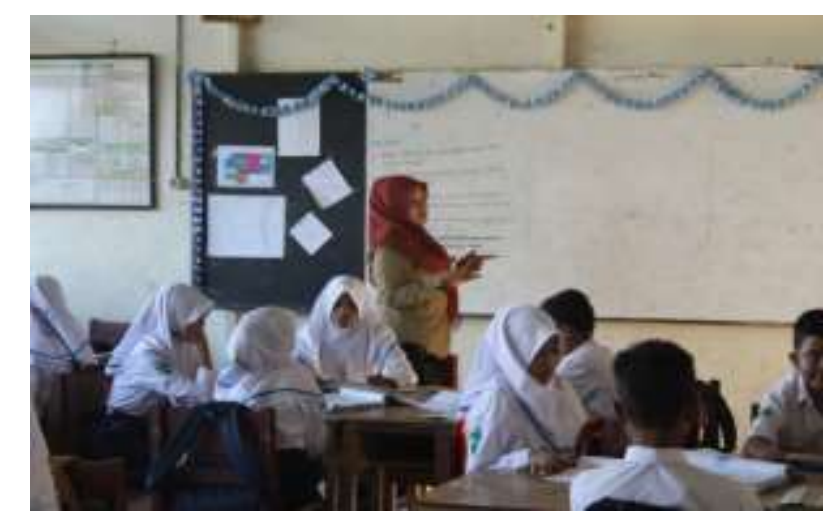

Gambar 2. Penyampaian Langkah-Langkah Kegiatan

c. Mengorganisir peserta didik ke dalam kelompok/tim

Berdasarkan hasil observasi, guru telah melaksanakan tahap ketiga dari model pembelajaran kooperatif. Dimana guru senantiasa mengorganisir peserta didik ke dalam kelompok-kelompok belajarnya dengan cara memberikan penjelasan kepada peserta didik tentang cara pembentukan kelompok belajar dan membantu peserta didik untuk melakukan transisi yang efisien, hal ini terlihat dalam setiap perpindahan peserta didik menuju kelompoknya, guru selalu mengingatkan posisi untuk masing-masing kelompok sehingga individu peserta didik yang merasa memiliki kelompok tersebut akan berkumpul keposisi yang telah ditetapkan guru. Guru juga selalu mengingatkan peserta didik untuk tidak membuat kegaduhan ketika berpindah menuju kelompoknya. Oleh karena itu, tahap ketiga dalam model pembelajaran kooperatif telah terlaksana dengan baik.

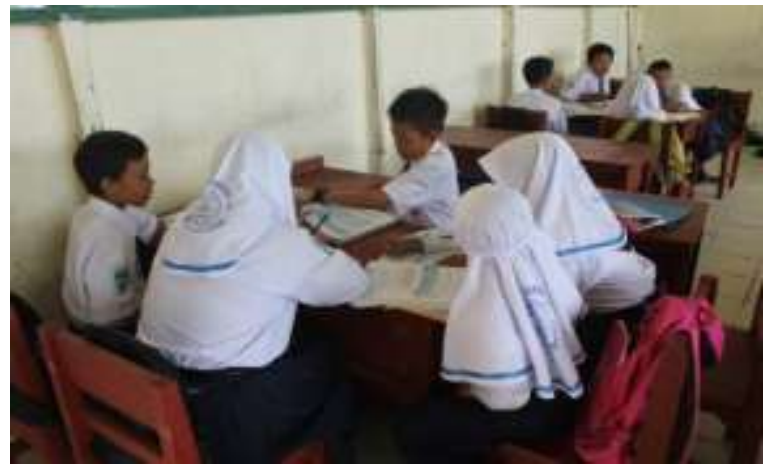

Gambar 3. Kelompok Belajar Peserta Didik 
Penerapan Model Pembelajaran Kooperatif Pada Mata Pelajaran Matematika Berdasarkan Kurikulum 2013 Di Kelas VII SMPN 13 Banjarmasin

d. Membantu kerja sama tim dan belajar

Berdasarkan hasil observasi, guru telah melaksanakan tahap keempat dari model pembelajaran kooperatif ini. Dimana guru senantiasa membantu dan membimbing kelompok-kelompok belajar selama peserta didik mengerjakan tugasnya. Hal ini terlihat bahwasanya guru senantiasa berkeliling kelas mengontrol setiap kelompok. Dalam kegiatan kelompok ini, peserta didik bekerja dengan pendekatan scientific, dimana masing-masing kelompok mendapat tugas untuk mengamati permasalahan yang telah diberikan guru melalui LKK, jika ada yang kurang jelas maka peserta didik diperbolehkan untuk bertanya. Jika ada kelompok yang kesulitan, guru membantu dengan memberikan penjelasan kepada peserta didik. Masing-masing kelompok mencoba menyelesaikan permasalahan tersebut dan saling mendiskusikan antar anggota kelompok untuk memperoleh jawaban yang berhubungan untuk menyelesaikan permasalahan tersebut. dan selama proses diskusi tersebut, guru senantiasa berkeliling untuk melihat tingkat pemahaman peserta didik dan siap membantu jika peserta didik memerlukan penjelasan maupun sedang kebingungan. Oleh karena itu, tahap keempat dalam model pembelajaran kooperatif telah terlaksana dengan baik dan relevan dengan pembelajaran menggunakan pendekatan scientific dalam Kurikulum 2013.

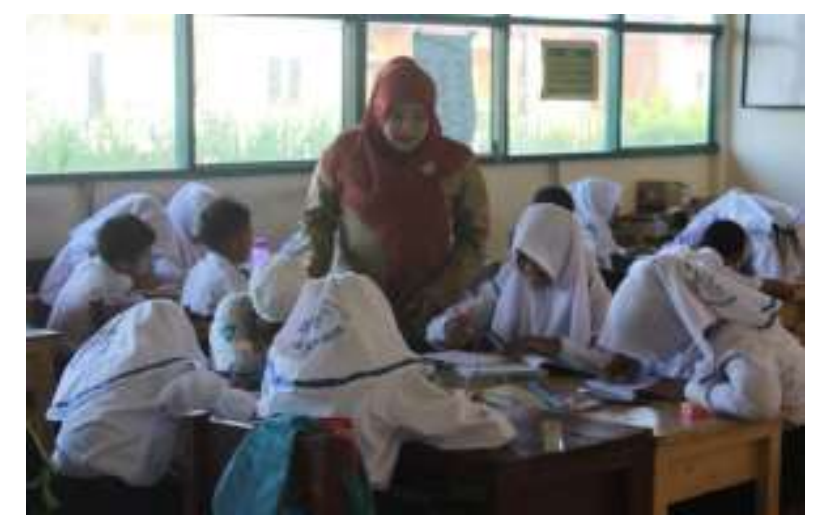

Gambar 4. Guru Membimbing Kelompok-Kelompok Belajar 
e. Mengevaluasi

Tahap mengevaluasi merupakan tahap dimana guru ingin melihat seberapa mampu peserta didik dalam menyelesaikan permasalahan yang diberikan guru. Pada tahap ini guru memberikan evaluasi dengan cara menguji pengetahuan peserta didik terhadap materi yang disajikan guru dalam permasalahan yang telah peserta didik selesaikan pada saat diskusi kelompok melalui presentasi hasil kerja peserta didik. Berdasarkan pendekatan scientific dalam Kurikulum 2013, tahap presentasi ini merupakan keterampilan peserta didik dalam mengkomunikasikan apa yang ingin mereka sampaikan dan bagaimana agar para pendengar mengerti apa yang mereka sampaikan. Melalui presentasi ini juga hasil pemahaman peserta didik terhadap materi akan terlihat dan disinilah tugas guru untuk memberikan penilaian dan meluruskan jika masih ada hasil presentasi yang keliru atau melenceng dari tujuan pembelajaran yang diharapkan. Oleh karena itu, tahap kelima dalam model pembelajaran kooperatif telah terlaksana dengan baik dan telah relevan dengan Kurikulum 2013.

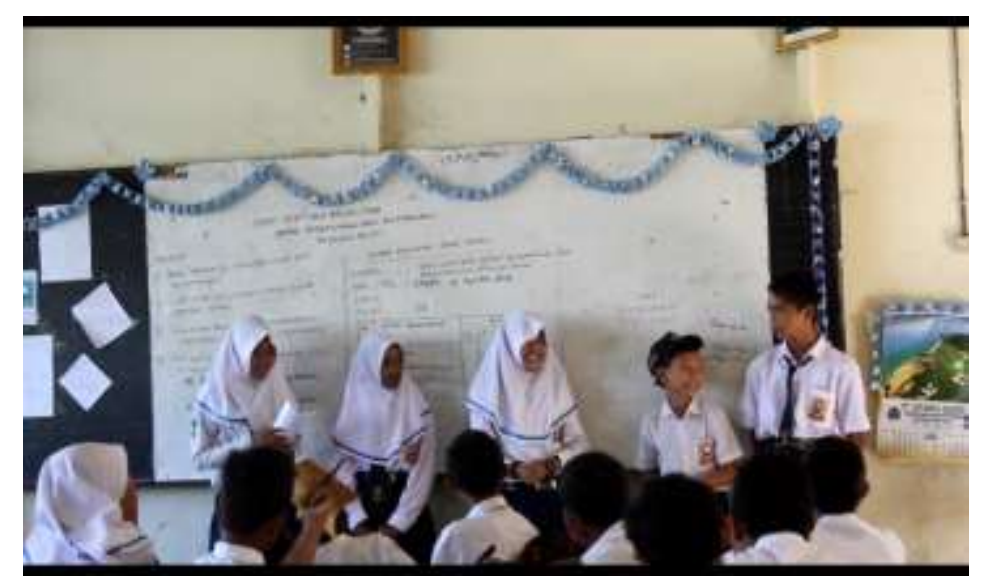

Gambar 5. Peserta didik mempresentasikan hasil kelompok

f. Memberikan pengakuan atau penghargaan

Berdasarkan hasil observasi, guru senantiasa memberikan reward atau penghargaan kepada peserta didik dalam setiap aksi 
Penerapan Model Pembelajaran Kooperatif Pada Mata Pelajaran Matematika Berdasarkan Kurikulum 2013 Di Kelas VII SMPN 13 Banjarmasin

mereka baik berupa tepuk tangan, puji-pujian, bintang prestasi, maupun tambahan nilai. Hal ini dilakukan agar peserta didik termotivasi untuk menjadi lebih baik lagi pada kesempatan selanjutnya. Oleh karena itu, tahap terakhir dalam model pembelajaran kooperatif ini telah terlaksana dengan baik.

\section{Tahap Penilaian}

Berdasarkan data yang telah disajikan, dapat dilihat bahwa evaluasi hasil belajar melalui penilaian yang dilakukan guru dalam aspek sikap, pengetahuan dan keterampilan telah sesuai dengan tuntutan kurikulum 2013. Berdasarkan hasil wawancara dengan guru, penilaian untuk aspek pengetahuan dilihat dari nilai pada setiap tugas baik tugas individu maupun kelompok. Namun dalam pelaksanaannya penilaian untuk aspek pengetahuan hanya dilakukan dengan pengambilan nilai pada hasil kelompok siswa dan tidak melakukan evaluasi secara individu, hal ini terjadi karena keterbatasan waktu untuk melakukan evaluasi untuk setiap individu peserta didik dalam setiap observasi, sehingga penilaian pengetahuan untuk setiap kali pertemuan dilihat dari hasil kelompok saja, dan untuk penilaian individu terhadap materi yang dipelajari nanti akan dilakukan pada akhir materi atau dinamakan latihan untuk materi yang telah dipelajari.

Untuk penilaian aspek sikap dilihat pada indikator-indikator yang telah diberitahukan pada peserta didik dalam setiap pembelajaran, untuk penilaian aspek sikap ini guru memberikan penilaian secara langsung sesuai indikator tersebut atau meminta peserta didik melakukan penilaian terhadap temannya. Dalam RPP yang dibuat guru juga mencantumkan teknik-teknik penilaian yang akan digunakan diantaranya untuk penilaian sikap spiritual guru melakukan penilaian dengan teknik penilaian diri, artinya setiap peserta didik memperoleh kesempatan untuk memberikan penilaian terhadap diri mereka sendiri yang berkaitan dengan indikator penilaian spiritual yang telah dibuat oleh guru, dan guru juga memberikan penilaian langsung untuk 
penilaian sikap spiritual peserta didik ini. Meskipun demikian untuk penilaian aspek spiritual ini dalam pelaksanaannya guru tidak memberikan penilaian pada setiap kali pertemuan, dan penilaian spiritual ini hanya guru saja yang memberikan penilaian tanpa melibatkan penilaian diri yang seharusnya dilakukan oleh peserta didik seperti yang direncanakan sebelumnya. Untuk penilaian sikap sosial guru melakukan penilaian dengan teknik penilaian antar teman, artinya peserta didik memberikan penilaian kepada temannya sesuai indikator penilaian yang telah disiapkan oleh guru, dan guru juga memberikan penilaian langsung untuk penilaian sikap sosial peserta didik ini.

Untuk penilaian aspek keterampilan, guru memberikan penilaian langsung yakni melalui pengamatan sesuai indikator yang disiapkan guru. Penilaian aspek keterampilan ini dapat dilihat melalui presentasi dengan indikator bagaimana tingkat pemahaman konsep yang dijelaskan, penampilan peserta didik saat presentasi, kemampuan berkomunikasi dan kemampuan mempertahankan jawaban/pendapat. Penilaian untuk aspek keterampilan juga dilihat dari hasil kerja proyek dan fortopolio peserta didik. Akan tetapi pada saat observasi, guru hanya melakukan penilaian terhadap keterampilan presentasi, dan sesekali melalui fortopolio yang dikumpulkan siswa, tetapi belum melakukan penilaian melalui hasil kerja proyek. Hanya saja, hasil penilaian terhadap keterampilan peserta didik ini belum dicantumkan guru dalam jurnal guru sehingga peneliti hanya bisa melampirkan format penilaian aspek keterampilannya saja.

\section{Kesimpulan}

Berdasarkan uraian mengenai penerapan model pembelajaran kooperatif berdasarkan Kurikulum 2013 di SMPN 13 Banjarmasin, dapat ditarik kesimpulan bahwa pada tahap perencanaan, guru telah membuat RPP yang sesuai dengan pedoman RPP pada Kurikulum 2013, dimana guru mencantumkan langkah-langkah pendekatan scientific yang mengandung 
Penerapan Model Pembelajaran Kooperatif Pada Mata Pelajaran Matematika Berdasarkan Kurikulum 2013 Di Kelas VII SMPN 13 Banjarmasin

komponen mengamati, menanya, mencoba, menalar, dan mengkomunikasikan, namun RPP yang dibuat guru belum mencantumkan langkah-langkah model pembelajaran kooperatif.

Pada tahap pelaksanaan pembelajaran telah sesuai dengan RPP yang dibuat guru meskipun ada beberapa hal yang belum terlaksana dan ada juga beberapa hal yang terlaksana diluar perencanaan yang dibuat, namun berdasarkan hasil analisis peneliti, pembelajaran dengan menggunakan pendekatan scientific telah terlaksana pada saat proses pembelajaran menggunakan model pembelajaran kooperatif.

Pada tahap penilaian, guru telah melakukan penilaian dalam berbagai aspek sesuai dengan tuntutan kurikulum 2013, meliputi penilaian pengetahuan, sikap dan keterampilan. Pada penilaian kompetensi sikap, guru menggunakan observasi baik dilakukan secara langsung oleh guru maupun meminta bantuan dari siswa melalui penilaian teman sejawat. Pada penilaian kompetensi pengetahuan, guru menggunakan tes tertulis dan penugasan. Dan penilaian kompetensi keterampilan guru menggunakan tes praktik dan fortopolio.

\section{Daftar Pustaka}

Afifuddin, et. al., 2009. Metodologi Penelitian Kualitatif. Bandung : Pustaka Setia.

Amri, Sofan, et. al., 2011. Implementasi Pendidikan Karakter Dalam Pembelajaran. Jakarta : PT. Prestasi Pustakaraya.

Aqib, Zainal,et. al., 2011. Panduan Dan Aplikasi Pendidikan Karakter. Bandung : Yrama Widya.

Bakhtiar,Amsal, 2004. Filsafat IImu. Jakarta : PT Raja Grafindo Persada.

Djamarah, Syaiful Bahri, 2010. Guru Dan Anak Didik Dalam Interaksi Edukatif. Jakarta : Rineka Cipta.

Isjoni, 2013. Cooperative Learning Efektivitas Pembelajaran Kelompok. Bandung : Alfabeta. 
Kementerian PendidikanDan Kebudayaan, 2013. Buku Teks Matematika Untuk SMP/MTs Kelas VII. Jakarta, Kementrian Pendidikan Dan Kebudayaan.

Kunandar, 2014. Penilaian Autentik (Penilaian Hasil Belajar Peserta Didik Berdasarkan Kurikulum 2013). Jakarta : Rajawali Press.

Mulyasa, 2013. Pengembangan Dan Implementasi Kurikulum 2013. Bandung : Remaja Rosdakarya.

Mulyono, 2011. Strategi Pembelajaran. Malang : UIN Maliki Press.

Muzamiroh, Mida Latifatul, 2013. Kupas Tuntas Kurikulum 2013. Kata pena.

Rusman, 2011. Model-Model Pembelajaran Mengembangkan Profesionalisme Guru. Jakarta : Rajawali Press.

Sanjaya, Wina, 2008. Pembelajaran Dalam Implementasi Kurikulum Berbasis Kompetensi. Jakarta : Kencana.

Sugiyono, 2010. Metode Penelitian Pendidikan Pendekatan Kuantitatif, Kualitatif, dan R\&D. Bandung : Alfabeta.

Suprijono, Agus, 2011. Cooperative Learning Teori Dan Aplikasi PAIKEM. Yogyakarta : Pustaka Pelajar.

\section{Fatmawati}

Mahasiswa Prodi PMTK, IAIN Antasari Banjarmasin

E-mail: -

\section{Sessi Rewetty Rivilla}

Dosen Prodi PMTK, IAIN Antasari Banjarmasin

E-mail: - 